\title{
Quality, Microstructure, and Technological Properties of Sheep Meat Marinated in Three Different Ways
}

\author{
Dessislava Borislavova Vlahova-Vangelova, ${ }^{1}$ Stefan Georgiev Dragoev, ${ }^{1}$ \\ Dessislav Kostadinov Balev, ${ }^{1}$ Bahytkul Kajkenovna Assenova, ${ }^{2}$ \\ and Kumarbek Junusbekovich Amirhanov ${ }^{2}$ \\ ${ }^{1}$ Department of Meat and Fish Technology, Technological Faculty, University of Food Technologies, 26 Maritza Blvd., \\ 4002 Plovdiv, Bulgaria \\ ${ }^{2}$ Department of Meat and Dairy Foods Production Engineering, Faculty of Engineering and Technology, \\ Shakarim State University of Semey, 20a Glinka Str., Semey 071400, Kazakhstan
}

Correspondence should be addressed to Dessislava Borislavova Vlahova-Vangelova; desislava_vangelova@abv.bg

Received 25 July 2016; Revised 1 November 2016; Accepted 21 November 2016; Published 16 January 2017

Academic Editor: Egidio De Benedetto

\begin{abstract}
Copyright ( 2017 Dessislava Borislavova Vlahova-Vangelova et al. This is an open access article distributed under the Creative Commons Attribution License, which permits unrestricted use, distribution, and reproduction in any medium, provided the original work is properly cited.
\end{abstract}

The objective of this study was to explore the effect of 24 and $48 \mathrm{~h}$ alkaline ( $2 \%$ pentasodium tripolyphosphate), acid ( $2 \%$ sodium lactate), and water-oil marinating (water: sun flavor oil $=1: 1$ and $2 \%$ salt) as well as brine soaking (2\% salt) on microstructure, changes in protein, and lipid fractions and technological properties of sheep ( $m$. Longissimus dorsi). Strong myofibrillar fragmentation after $48 \mathrm{~h}$ alkaline marinating was observed. Significant swelling and increasing of spaces between myofibrils were found after $24 \mathrm{~h}$ brine soaking. Marinating in water-oil emulsions did not show a significant impact on the muscle microstructure. Alkaline and acid marinating as well as salt soaking promote the myofibrillar protein solubility and increased the free amino nitrogen content. After $24 \mathrm{~h}$ acid and $48 \mathrm{~h}$ alkaline marinating SDS-PAGE electrophoresis showed increasing of $25-$ $30 \mathrm{kDa}$ protein bands. The results obtained for the lipid and protein oxidation confirm prooxidant action of the sodium lactate (2\%) and antioxidant effect of polyphosphates (2\%) in marinated sheep.

\section{Introduction}

Marinating is a simple technological treatment used to improve the functional and sensory properties of meat by soaking, injecting, or tumbling with aqueous solutions, composed of different ingredients [1].

While alkaline marinade solutions contain salt-phosphate mixture, acid solutions contain organic acids or their salts. The third type is water-oil emulsions which contain salt, sugar, vinegar or citric acid, and other supplements.

Sheep is traditional and preferred meat for consumers in Kazakhstan. In Bulgaria significant part from livestock belongs to sheep population. Meat from these animals contains larger amount of cross-linked collagen and is usually tough [2]. It is known that the meat tenderness is one of the most important factors affecting the meat consumers satisfaction [3]. In the postmortem period meat tenderness is influenced by the proteolysis of myofibrillar and connective tissue proteins. Breaks in the sarcomeres occur and meat becomes tendered. Probably calcium-dependent enzymes play the most important role in the proteolytic changes in meat [4].

Injection of marinade solutions had a positive effect on meat tenderness [5]. The addition of phosphates such us sodium tripolyphosphate increases water holding capacity due to protein extraction and shifting of the $\mathrm{pH}$ from the muscle proteins isoelectric point [6]. Sodium carbonate and bicarbonate are known to be superior marinating agents, which reduce drip loss and improved yield [7]. Marinating with alkaline phosphates decreases the shear force and consequently increases meat tenderness [8]. 
The use of organic acids during marinating had the strong effect on muscle fibers and connective tissue and enhances tenderness. Citric acid, a food acidulant, not only is often used in acid marinating to improve the water holding capacity and tenderness of beef muscle but is also commonly used as a chelator to control the activity of prooxidant metals [9]. Lactic acid is often used in the meat industry as an antimicrobial agent [10]. But marinade solutions with lactic acid did not improve meat juiciness probably due to the high loss of meat juice during cooking [11].

Spices and herbs added in marinades significantly enhance meat safety [12].

The influence of different types of marination on the meat microstructure and quality was discussed about poultry $[1,13,14]$, turkey $[5,15]$, pork [16], and beef [17-20]. Only few studies focus on marinating effects on microstructural, proteolytical, and oxidative changes in sheep.

Considering all these aspects, the aim of this study was to investigate the effects of alkaline, acid, and water-oil marination, as well as brine soaking, on sheep quality by monitoring the changes of microstructure, hydrolytic and oxidative processes, and some technological properties.

\section{Materials and Methods}

2.1. Materials. The fresh ( $1 \mathrm{~h}$ postmortem) sheep $m$. Longissimus dorsi with $\mathrm{pH} 6.95$ was supplied by the company Unitemp Ltd., Voyvodinovo Village, District Plovdiv, Bulgaria. Sheep $m$. Longissimus dorsi was cut into thirty pieces $(100 \times 60 \times 20 \mathrm{~mm}$, each weighting approx. $50 \mathrm{~g})$. Sodium lactate (60\% aqueous solution) was purchased by “Teokom" Ltd. (Sofia, Bulgaria). Sodium tripolyphosphate (E451) was supplied by the company "FILLAB" Ltd. (Sofia, Bulgaria). Sodium chloride (salt), sugar, and sunflower oil were bought from the local market.

2.2. Sample Preparation. Four types of solutions were used. The alkaline marinating solution (ALS) was prepared with $2 \%$ polyphosphates (E 451) and $2 \%$ salt added in water. The $\mathrm{pH}$ of alkaline marinating solution (ALS) was 8.0. The acid marinating solution (ACS) was prepared with $2 \%$ sodium lactate and $2 \%$ salt added in water. The $\mathrm{pH}$ of acid marinating solution (ACS) was 6.75. The water-oil marinating solution (WOS) was made as mixture of water and sunflower oil (1:1) with $2 \%$ salt addition. The $\mathrm{pH}$ of water-oil marinating solution (WOS) was 6.9. The brine soaking solution (BSS) represents $2 \%$ salt water solution with $\mathrm{pH} 6.85$. All solutions (ALS, ACS, WOS, and BSS) were cooled to the temperature of $4^{\circ} \mathrm{C}$ and used for meat marinating. The meat samples $(m$. Longissimus dorsi) were added to marinating solutions in ratio $1: 2$ and separately stored in closed plastic boxes at 0$4^{\circ} \mathrm{C}$ for $24 \mathrm{~h}$ and $48 \mathrm{~h}$. The test samples were as follows: AL24: alkaline marinated sheep for $24 \mathrm{~h}, \mathrm{AC} 24$ : acid marinated sheep for $24 \mathrm{~h}$, WO24: water-oil marinated sheep for $24 \mathrm{~h}$, BS24: soaked in salt solution sheep for $24 \mathrm{~h}$, AL48: alkaline marinated sheep for $48 \mathrm{~h}, \mathrm{AC} 48$ : acid marinated sheep for 48 h, WO48: water-oil marinated sheep for $48 \mathrm{~h}$, and BS48: soaked in salt solution sheep for $48 \mathrm{~h}$. Individual measurements were defined for marinade solutions (ALS, ACS, WOS, and BSS, resp.). The control samples ( $m$. Longissimus dorsi) at $4 \mathrm{~h}$ postmortem (C0) were measured immediately. The other control samples were stored separately in plastic bags for 2 days in air conditions at $0-4^{\circ} \mathrm{C}$ and were measured at $24 \mathrm{~h}$ postmortem $(\mathrm{C} 24)$ as well as at $48 \mathrm{~h}$ postmortem $(\mathrm{C} 48)$.

2.3. Methods. Microstructural analysis was carried out as described by Lawrence et al. [21]. Marinated and control samples $(10 \mathrm{~mm} \times 2 \mathrm{~mm} \times 2 \mathrm{~mm})$ were soaked for $24 \mathrm{~h}$ at $4^{\circ} \mathrm{C}$ in a $0.2 \mathrm{M}$ glutaraldehyde solution with $0.2 \mathrm{M}$ sodium cacodylate buffer ( $\mathrm{pH} 7.4$ ), rinsed 5 times in $0.2 \mathrm{M}$ sodium cacodylate buffer, and fixed in $4 \%$ osmium tetroxide in $0.2 \mathrm{M}$ sodium cacodylate buffer for $2 \mathrm{~h}$ at $4^{\circ} \mathrm{C}$. The samples were dehydrated with $50 \%, 70 \%, 96 \%$, and $100 \%$ ethanol for $30 \mathrm{~min}$ at each concentration with constant agitation and then stored overnight in $100 \%$ ethanol at $4^{\circ} \mathrm{C}$. The samples were then soaked to propylene oxide for $30 \mathrm{~min}$, mixed in epoxy with propylene oxide for $30 \mathrm{~min}$, and coated in fresh epoxy and hardened by heating at $56^{\circ} \mathrm{C}$ for $48 \mathrm{~h}$. Samples were sliced to a thickness of $60 \mathrm{~nm}$ and the sections were mounted on bare 200-mesh hex copper grids. The grids were stained in a saturated solution of uranyl acetate in $50 \%$ ethanol for $30 \mathrm{~min}$, followed by staining in alkaline lead citrate solution for $3 \mathrm{~min}$. The samples were observed on a JEM-1200EX/ASID transmission electron microscope (JEOL, Japan) at $12000 \mathrm{x}$ and photographed on film that was scanned at $600 \mathrm{dpi}$ on a flatbed transparency scanner.

Extraction of myofibrillar proteins was carried out with PBS buffer $\left(49 \mathrm{mM} \mathrm{Na} \mathrm{Na}_{2} \mathrm{HPO}_{4} \cdot 7 \mathrm{H}_{2} \mathrm{O}\right.$ and $4.5 \mathrm{mM}$ $\mathrm{NaH}_{2} \mathrm{PO}_{4} \cdot \mathrm{H}_{2} \mathrm{O}$ and $\mathrm{KCl}$, ionic strength 0.55 , and $\mathrm{pH}=7.3$ ), according to the procedure described by Khan [22] with some modifications. The chopped muscle tissue $(2.5 \mathrm{~g})$ was homogenized with $48.5 \mathrm{~cm}^{3}$ PBS buffer and stored at $0-4^{\circ} \mathrm{C}$ for $24 \mathrm{~h}$. The homogenate was centrifugated at $3000 \times \mathrm{g}$ for $15 \mathrm{~min}$. SDS-PAGE was carried out using $10 \%$ gels at a constant voltage mode $(200 \mathrm{~V})$ in an Omni PAGA Electrophoresis System (Cleaver Scientific Ltd.). Protein markers were obtained from Precision Plus Protein ${ }^{\mathrm{TM}}$ Standards (Bio-Rad Laboratories, Inc., Hercules, USA).

The myofibrillar proteins concentration was determined spectrophotometrically at $750 \mathrm{~nm}$ [23] with double beam UV-VIS spectrophotometer Camspec model M550 (Camspec Ltd., Cambridge, UK).

Free amino nitrogen (FAN) was determined by modified titration method of Sørensen [24]. The absorption was measured with double beam UV-VIS spectrophotometer Camspec model M550 (Camspec Ltd., Cambridge, UK) at $570 \mathrm{~nm}$.

Protein oxidation was measured by estimation of formed carbonyl groups [25]. Protein concentration was calculated at $280 \mathrm{~nm}$ in the $\mathrm{HCl}$ control using BSA in $6 \mathrm{M}$ guanidine as standard. Carbonyl concentration was measured on the treated sample by measuring DNPH incorporated on the basis of absorption of $21.0 \mathrm{mM}^{-1} \mathrm{~cm}^{-1}$ at $370 \mathrm{~nm}$ for protein hydrazones. The results were expressed as nanomoles of DNPH fixed per milligram of protein.

2.4. Extraction of Total Lipids. The extraction of total lipids was carried out following Bligh and Dyer method [26]. After homogenization, a hundred $\mathrm{g}$ of sample was mixed with 
TABLE 1: Changes of the soluble proteins and the free amino nitrogen content of marinated sheep and marinating solutions.

\begin{tabular}{|c|c|c|c|c|c|}
\hline Sample & $\begin{array}{l}\text { Soluble proteins } \\
\quad\left(\mathrm{mg} \cdot \mathrm{ml}^{-1}\right)\end{array}$ & $\begin{array}{l}\text { Free amino nitrogen, } \\
\quad\left(\mathrm{mgLeu} \cdot \mathrm{g}^{-1}\right)\end{array}$ & Solutions & $\begin{array}{l}\text { Soluble proteins } \\
\quad\left(\mathrm{mg} \cdot \mathrm{ml}^{-1}\right)\end{array}$ & $\begin{array}{l}\text { Free amino nitrogen } \\
\left(\mathrm{mgLeu}^{-1} \mathrm{~g}^{-1}\right)\end{array}$ \\
\hline \multicolumn{4}{|c|}{ Marinated meat } & \multicolumn{2}{|c|}{ Marinating solutions } \\
\hline $\mathrm{C} 24$ & $1.33^{\mathrm{b}} \pm 0.14$ & $13.33^{\mathrm{b}, \mathrm{c}} \pm 0.21$ & & - & - \\
\hline AL24 & $3.48^{\mathrm{d}} \pm 0.19$ & $19.50^{g} \pm 0.32$ & ALS24 & $3.20^{\mathrm{e}} \pm 0.20$ & $2.81^{b} \pm 0.08$ \\
\hline AC24 & $3.36^{\mathrm{d}} \pm 0.22$ & $15.80^{\mathrm{f}} \pm 0.18$ & ACS24 & $1.88^{\mathrm{a}, \mathrm{b}} \pm 0.12$ & $3.42^{\mathrm{d}} \pm 0.12$ \\
\hline WO24 & $2.90^{\mathrm{c}} \pm 0.15$ & $12.94^{\mathrm{b}} \pm 0.15$ & WOS24 & $2.25^{\mathrm{c}} \pm 0.14$ & $2.90^{\mathrm{b}} \pm 0.15$ \\
\hline BS24 & $3.60^{\mathrm{d}} \pm 0.18$ & $20.09^{\mathrm{g}} \pm 0.17$ & BSS24 & $3.90^{\mathrm{f}} \pm 0.12$ & $2.64^{\mathrm{a}, \mathrm{b}} \pm 0.09$ \\
\hline C48 & $0.79^{\mathrm{a}} \pm 0.08$ & $9.91^{\mathrm{a}} \pm 0.20$ & & - & - \\
\hline AL48 & $1.36^{\mathrm{b}} \pm 0.15$ & $15.00^{\mathrm{e}} \pm 0.15$ & ALS48 & $2.56^{\mathrm{d}} \pm 0.05$ & $2.61^{\mathrm{a}} \pm 0.10$ \\
\hline AC48 & $1.32^{\mathrm{b}} \pm 0.12$ & $13.55^{c} \pm 0.18$ & ACS48 & $1.78^{\mathrm{a}} \pm 0.07$ & $3.17^{\mathrm{C}} \pm 0.12$ \\
\hline WO48 & $1.30^{\mathrm{b}} \pm 0.10$ & $14.20^{\mathrm{d}} \pm 0.25$ & WOS48 & $2.00^{b, c} \pm 0.11$ & $2.77^{\mathrm{a}, \mathrm{b}} \pm 0.09$ \\
\hline BS48 & $5.10^{\mathrm{e}} \pm 0.08$ & $25.03^{\mathrm{h}} \pm 0.22$ & BSS48 & $4.40^{\mathrm{g}} \pm 0.18$ & $3.50^{\mathrm{d}} \pm 0.17$ \\
\hline
\end{tabular}

Mean value \pm SE. ${ }^{\mathrm{a}, \mathrm{b}, \mathrm{c}, \mathrm{d}, \mathrm{e}, \mathrm{f}, \mathrm{g}, \mathrm{h}}$ Different letters (in columns) on the means with statistical differences at $24 \mathrm{~h}$ or $48 \mathrm{~h}$ marinated samples $(P \leq 0.05)$. ALS24: alkaline marinating solution ( $2 \%$ polyphosphates (E 451 ) and $2 \%$ salt) after $24 \mathrm{~h}$ treatment; ACS24: acid marinating solution ( $2 \%$ sodium lactate and $2 \%$ salt) after $24 \mathrm{~h}$ treatment; WOS24: water-oil marinating solution (water and sunflower oil (1:1) with $2 \%$ salt) after $24 \mathrm{~h}$ treatment; BSS24: brine solution (2\% salt water solution) after $24 \mathrm{~h}$ treatment; ALS48: alkaline marinating solution ( $2 \%$ polyphosphates (E 451 ) and $2 \%$ salt) after $48 \mathrm{~h}$ treatment; ACS48: acid marinating solution ( $2 \%$ sodium lactate and $2 \%$ salt) after $48 \mathrm{~h}$ treatment; WOS48: water-oil marinating solution (water and sunflower oil ( $1: 1)$ with $2 \%$ salt) after $48 \mathrm{~h}$ treatment; BSS48: brine solution (2\% salt water solution) after $48 \mathrm{~h}$ treatment; $\mathrm{C} 0$ : control samples at $4 \mathrm{~h}$ postmortem; C24: control samples at $24 \mathrm{~h}$ postmortem; C48: control samples at $48 \mathrm{~h}$ postmortem; AL24: alkaline marinated sheep for $24 \mathrm{~h}$; AC24: acid marinated sheep for $24 \mathrm{~h}$; WO24: water-oil marinated sheep for 24 h; BS24: soaked in salt solution sheep for $24 \mathrm{~h}$; AL48: alkaline marinated sheep for 48 h; AC48: acid marinated sheep for 48 h; WO48: water-oil marinated sheep for $48 \mathrm{~h}$; BS48: soaked in salt solution sheep for $48 \mathrm{~h}$.

$300 \mathrm{~mL}$ chloroform and $200 \mathrm{~mL}$ methanol. After filtration the final biphasic system was separated and the chloroform phase was collected. Lipid content was determined after evaporating of chloroform phase to dryness under nitrogen.

Acid value $(A V)$ of the extracted lipids was measured following EN ISO 660:2001 procedure based on the acidbase titration techniques in nonaqueous solvents [27]. One gram of fat was digested with $20 \mathrm{~mL}$ neutral alcohol-ether mixture $(1: 2)$ with few drops of phenolphthalein addition. The mixture was titrated with $0,01 \mathrm{~N} \mathrm{KOH}$ to pale pink colorisation. Acid value (AV) was expressed as the amount of $\mathrm{KOH}$ (in milligrams) necessary to neutralize free fatty acids contained in $1 \mathrm{~g}$ of oil.

Peroxide value (POV) of the tested samples was measured by the oxidation of $\mathrm{Fe}^{2+}$ to $\mathrm{Fe}^{3+}$ in the presence of hydroperoxides [28]. The absorption was measured with double beam UV-VIS spectrophotometer Camspec model M550 (Camspec Ltd., Cambridge, UK) at $507 \mathrm{~nm}$.

TBARS were determined by the method described by Botsoglou et al. [29]. The double beam UV-VIS spectrophotometer Camspec model M550 (Camspec Ltd., Cambridge, UK) was used.

The $\mathrm{pH}$ of the marinating solutions was measured directly [30] with pH-meter Microsyst MS 2004 (Microsyst, Plovdiv, Bulgaria), equipped by combined $\mathrm{pH}$ electrode Sensorex combination recorder S $450 \mathrm{CD}$ (Sensorex $\mathrm{pH}$ Electrode Station, Garden Grove, CA, USA).

The water holding capacity (WHC) was measured according to Modzelewska-Kapitula and Cierach procedure [31]. One meat cut $(0,3 \mathrm{~g})$ was placed on filter paper between two glass plates and pressed with a $1 \mathrm{~kg}$ weight for $10 \mathrm{~min}$. The water holding capacity was determined as difference between the areas of the two spots by planimeter measuring.

Calculations for percentage marinade uptake and cooking loss were as follows: $\%$ marinade uptake $=$ marinated weight - raw weight/raw weight $\times 100$ [18]; \% cooking loss $=100 \times$ (raw weight - cooked weight)/raw weight [5].

2.5. Statistical Analysis. All the analyses were replicated nine times $(n=9)$. Results were expressed as means \pm standard error (SE). Statistical analyses were conducted using SPSS 11.0 software (SPSS Inc., Chicago, Illinois, USA). Data were analyzed independently by ANOVA software (Excel 5.0). The Duncan multiple comparison test was used to determine the differences between the mean values. If $P$ values for the differences between the means were less than 0.05 , they were considered statistically significant.

\section{Results and Discussion}

\subsection{Proteolytical Changes in Marinated Sheep and Marinating Solutions}

3.1.1. Changes in Myofibrillar Protein Solubility. Compared to the control samples (C24, Table 1), alkaline and acid marinating (AL24, AC24) as well as salt soaking (BS24) increased up to four times the solubility of myofibrillar protein fraction. This data correspond to [7] study for poultry marinating.

After $24 \mathrm{~h}$ treatment, the greatest amount of soluble proteins was extracted in salt solution (BS24) and in alkaline solution (AL24). 
TABLE 2: Changes of the total protein carbonyls, acid value, peroxide value, and TBARS of the marinated sheep.

\begin{tabular}{|c|c|c|c|c|}
\hline Sample & $\begin{array}{l}\text { Protein carbonyls, } \\
\mathrm{nmol} \cdot \mathrm{mg}^{-1} \text { proteins }\end{array}$ & $\begin{array}{l}\text { Acid value, } \\
\mathrm{mg} \mathrm{KOH} \cdot \mathrm{g}^{-1}\end{array}$ & $\begin{array}{l}\text { Peroxide value, } \\
\mu \mathrm{eqO}_{2} \cdot \mathrm{kg}^{-1}\end{array}$ & $\begin{array}{c}\text { TBARS, } \\
\mathrm{mg} \mathrm{MDA} \cdot \mathrm{kg}^{-1}\end{array}$ \\
\hline $\mathrm{C} 24$ & $0.14^{\mathrm{b}} \pm 0.008$ & $0.33^{b, c} \pm 0.04$ & $0.30^{\mathrm{d}} \pm 0.012$ & $0.45^{\mathrm{d}} \pm 0.02$ \\
\hline AL24 & $0.11^{\mathrm{a}} \pm 0.008$ & $0.34^{\mathrm{c}} \pm 0.03$ & $0.23^{b} \pm 0.009$ & $0.20^{\mathrm{a}} \pm 0.01$ \\
\hline $\mathrm{AC} 24$ & $0.16^{\mathrm{c}, \mathrm{d}} \pm 0.009$ & $0.46^{\mathrm{d}} \pm 0.05$ & $0.18^{\mathrm{a}} \pm 0.007$ & $0.65^{\mathrm{e}} \pm 0.02$ \\
\hline WO24 & $0.15^{\mathrm{b}, \mathrm{c}} \pm 0.005$ & $0.46^{\mathrm{d}} \pm 0.03$ & $0.26^{\mathrm{c}} \pm 0.008$ & $0.24^{\mathrm{b}} \pm 0.01$ \\
\hline BS24 & $0.15^{\mathrm{b}, \mathrm{c}} \pm 0.007$ & $0.38^{\mathrm{c}} \pm 0.03$ & $0.29^{\mathrm{d}} \pm 0.010$ & $0.35^{\mathrm{c}} \pm 0.01$ \\
\hline $\mathrm{C} 48$ & $0.16^{\mathrm{c}, \mathrm{d}} \pm 0.008$ & $0.37^{\mathrm{c}} \pm 0.04$ & $0.31^{\mathrm{d}} \pm 0.015$ & $0.47^{\mathrm{d}} \pm 0.02$ \\
\hline AL48 & $0.12^{\mathrm{a}} \pm 0.005$ & $0.25^{\mathrm{b}} \pm 0.05$ & $0.22^{\mathrm{b}} \pm 0.008$ & $0.22^{\mathrm{a}, \mathrm{b}} \pm 0.01$ \\
\hline $\mathrm{AC} 48$ & $0.20^{\mathrm{e}} \pm 0.006$ & $0.12^{\mathrm{a}} \pm 0.04$ & $0.38^{\mathrm{f}} \pm 0.013$ & $0.37^{\mathcal{c}} \pm 0.01$ \\
\hline WO48 & $0.16^{\mathrm{c}, \mathrm{d}} \pm 0.008$ & $0.35^{\mathrm{b}, \mathrm{c}} \pm 0.06$ & $0.34^{\mathrm{e}} \pm 0.011$ & $0.26^{\mathrm{b}} \pm 0.01$ \\
\hline BS48 & $0.17^{\mathrm{d}} \pm 0.009$ & $0.30^{\mathrm{b}} \pm 0.02$ & $0.42^{\mathrm{g}} \pm 0.013$ & $0.37^{\mathcal{c}} \pm 0.02$ \\
\hline
\end{tabular}

Mean value \pm SE. ${ }^{\mathrm{a}, \mathrm{b}, \mathrm{c}, \mathrm{d}, \mathrm{e}, \mathrm{f}, \mathrm{g}}$ Different letters (in columns) on the means with statistical differences at $24 \mathrm{~h}$ or $48 \mathrm{~h}$ marinated samples $(P \leq 0.05)$. C24: control samples at $24 \mathrm{~h}$ postmortem; C48: control samples at $48 \mathrm{~h}$ postmortem; AL24: alkaline marinated sheep for $24 \mathrm{~h}$; AC24: acid marinated sheep for $24 \mathrm{~h}$; WO24: water-oil marinated sheep for $24 \mathrm{~h}$; BS24: soaked in salt solution sheep for $24 \mathrm{~h}$; AL48: alkaline marinated sheep for $48 \mathrm{~h}$; AC48: acid marinated sheep for $48 \mathrm{~h}$; WO48: water-oil marinated sheep for $48 \mathrm{~h}$; BS48: soaked in salt solution sheep for $48 \mathrm{~h}$.

Meat soaking with $2 \%$ sodium chloride for $48 \mathrm{~h}$ showed the greatest impact on the solubility of myofibrillar protein fraction (BS48, Table 1). These results were expected due to proven action of $\mathrm{Cl}^{-}$ions in salt soaking [7] and phosphate effect in alkaline marinating [32]. The known effect of phosphate addition on myofibrillar solubility was not observed.

\subsubsection{Changes in Free Amino Nitrogen (FAN) Content. After} $24 \mathrm{~h}$ marinating proteolytical change associated with an increase in free amino nitrogen (FAN) was established in all studied samples (Table 1). Compared to the control samples (C24), the FAN content increased 2.7 times in salt soaked sheep (BS24, $P \leq 0.05$ ) and 2.62 times in alkaline marinated sheep (AL24, $P \leq 0.05$ ). After $24 \mathrm{~h}$ acid marinating (AC24) the FAN content increased 2.53 times $(P \leq 0.05)$. The slight increase in FAN content was found in water-oil marinated sheep (WO24, $P \leq 0.05$ ). Other researches showed that with increasing salt or acid concentration the amount of total nitrogen compound in fish was lower [33].

With the extending of marinating time to $48 \mathrm{~h}$ statistically significant decreasing in FAN content $(P \leq 0.05)$ in all studied samples was obtained (Table 1).

3.1.3. SDS-PAGE Electrophoresis. After $24 \mathrm{~h}$ marinating the $200 \mathrm{KDa}$ polypeptides (heavy meromyosin) were identified in all samples (Figure 3). In control samples, polypeptides with this molecular weight were identified only at $4 \mathrm{~h}$ postmortem (C0, Figure 2). This finding confirms that the marinating processes leads to proteolytical changes in muscle tissue (Figure 3). In the $48 \mathrm{~h}$ marinating sheep $200 \mathrm{KDa}$ protein bands were not extracted from muscle tissue possibly due to proteolysis and passing of these fractions into marinating solutions. Water-oil marinating was not enough effective for extraction of heavy meromyosin chains (WO24, WO48, Figure 3).

The postmortem degradation of muscle proteins is important factor for developing of meat tenderness [33].
As is known the presence of 28 and $30 \mathrm{kDa}$ polypeptides is associated with the degradation of troponin-T and is a key indicator of the meat aging [34]. The $25-30 \mathrm{kDa}$ protein bands were increasing in muscle tissue after $24 \mathrm{~h}$ acid marinating (AL24) and $48 \mathrm{~h}$ alkaline marinating (AL48). The largest amount of these fractions was identified in all marinating solutions (Figure 4).

After $48 \mathrm{~h}$ marinating the protein fractions in marinating solutions increased due to the passage of protein fractions in the marinade solutions (Figure 4). The accumulation of low molecular weight protein fractions in the studied samples (Figure 3) and marinating solutions (Figure 4) shows that the extension of marinating time to $48 \mathrm{~h}$ increased the proteolytic changes in marinated meat.

The largest numbers of protein bands were identified in 48 h soaked sheep (BS48, Figure 3 ). In this sample the greatest amount of heavy meromyosin (MHC) was extracted.

The results obtained (Figure 4 ) show that the $2 \%$ brine solutions as well as $2 \%$ sodium tripolyphosphate solutions influenced to the largest extent proteolytical changes in sheep. The significant proteolytical changes in marinated as well as in soaked sheep were confirmed by the data observed for protein solubility and FAN content (Table 1).

3.1.4. Protein Oxidation. It was found that brine soaking (BS) and water-oil (WO) marinating slightly influenced $(P>$ 0.05 ) protein oxidation in sheep (Table 2 ). The same trend was found after $48 \mathrm{~h}$ marinating (control $48 \mathrm{~h}, \mathrm{AC} 48$, and BS48). The increasing of carbonyl groups and decreasing of $\mathrm{pH}$ established after acid marinating confirmed previous researches [35].

In comparison to the control samples (C24, C48, Table 2), after $24 \mathrm{~h}$ and $48 \mathrm{~h}$ alkaline marinating, the protein carbonyls content decreased by $30 \%(P \leq 0.05)$.

The opposite trend was established after acid marinating (AC24, AC48, Table 2). Compared to control samples C24, the carbonyl content in AC24 increases by $20 \%(P \leq 0.05)$. The extension of marinating time to $48 \mathrm{~h}$, increased by 
TABLE 3: Changes of the $\mathrm{pH}$, water holding capacity, weight gain, and cooking loss of marinated sheep.

\begin{tabular}{lcccc}
\hline Sample & $\mathrm{pH}$ & $\begin{array}{c}\text { Water holding } \\
\text { capacity (\%) }\end{array}$ & $\begin{array}{c}\text { Weight } \\
\text { gain (\%) }\end{array}$ & $\begin{array}{c}\text { Cooking } \\
\text { loss }(\%)\end{array}$ \\
\hline C24 & $6.20^{\mathrm{b}} \pm 0.02$ & $9.75^{\mathrm{a}} \pm 0.72$ & - & $40.20^{\mathrm{a}} \pm 1.05$ \\
AL24 & $6.92^{\mathrm{e}, \mathrm{f}} \pm 0.09$ & $20.31^{\mathrm{b}} \pm 0.85$ & $14.82^{\mathrm{b}} \pm 2.67$ & $41.40^{\mathrm{a}} \pm 1.69$ \\
$A C 24$ & $6.60^{\mathrm{c}} \pm 0.02$ & $19.86^{\mathrm{b}} \pm 1.05$ & $14.15^{\mathrm{b}} \pm 3.99$ & $41.10^{\mathrm{a}} \pm 2.45$ \\
$W O 24$ & $6.70^{\mathrm{d}} \pm 0.02$ & $9.75^{\mathrm{a}} \pm 0.90$ & $7.23^{\mathrm{a}} \pm 2.07$ & $40.05^{\mathrm{a}} \pm 2.14$ \\
$B S 24$ & $6.85^{\mathrm{e}} \pm 0.08$ & $21.22^{\mathrm{b}} \pm 1.23$ & $-99^{\mathrm{b}} \pm 5.32$ & $43.45^{\mathrm{a}} \pm 2.48$ \\
\hline$C 48$ & $6.00^{\mathrm{a}} \pm 0.02$ & $9.75^{\mathrm{a}} \pm 0.72$ & $22.53^{\mathrm{c}} \pm 3.91$ & $40.40^{\mathrm{a}} \pm 1.00$ \\
$A L 48$ & $7.07^{\mathrm{g}} \pm 0.05$ & $24.27^{\mathrm{c}} \pm 0.85$ & $21.99^{\mathrm{c}} \pm 3.11$ & $41.90^{\mathrm{a}} \pm 1.15$ \\
$A C 48$ & $6.97^{\mathrm{f}} \pm 0.01$ & $21.16^{\mathrm{b}} \pm 1.05$ & $13.02^{\mathrm{b}} \pm 1.15$ & $41.75^{\mathrm{a}} \pm 1.17$ \\
$W O 48$ & $6.87^{\mathrm{e}} \pm 0.07$ & $9.86^{\mathrm{a}} \pm 0.90$ & $22.86^{\mathrm{c}} \pm 2.69$ & $41.85^{\mathrm{a}} \pm 1.36$ \\
$B S 48$ & $7.00^{\mathrm{f}} \pm 0.01$ & $25.03^{\mathrm{c}} \pm 1.23$ & $46.15^{\mathrm{b}} \pm 1.17$ \\
\hline
\end{tabular}

Mean value \pm SE. ${ }^{\text {a,b,c,de, }, \mathrm{f}}$ Different letters (in columns) on the means with statistical differences at $24 \mathrm{~h}$ or $48 \mathrm{~h}$ marinated samples $(P \leq 0.05)$. C24: control samples at $24 \mathrm{~h}$ postmortem; C48: control samples at $48 \mathrm{~h}$ postmortem; AL24: alkaline marinated sheep for $24 \mathrm{~h}$; AC24: acid marinated sheep for $24 \mathrm{~h}$; WO24: water-oil marinated sheep for $24 \mathrm{~h}$; BS24: soaked in salt solution sheep for $24 \mathrm{~h}$; AL48: alkaline marinated sheep for $48 \mathrm{~h}$; AC48: acid marinated sheep for $48 \mathrm{~h}$; WO48: water-oil marinated sheep for $48 \mathrm{~h}$; BS48: soaked in salt solution sheep for $48 \mathrm{~h}$.

$28.20 \%$ protein oxidation in acid marinated sheep (AC48). Sharedeh et al. [35] explain that free amino groups ( $\mathrm{NH}$ or NH2) are very sensitive to the free oxygenated radicals generated by the $\mathrm{pH}$ decrease. Decrease of carbonyl content in alkaline marinated sheep was in agreement with the known protective effect of phosphates on protein oxidation [32].

\subsection{Lipolytic Changes in Marinated Sheep}

3.2.1. Acid Value (AV). After $48 \mathrm{~h}$ the free fatty acids content in water-oil marinating sheep (WO48) increased two times $(P \leq 0.05)$, compared to alkaline marinated meat. The observed AV was not surprising because these samples had oil addition and as a result the lipolytic processes in wateroil marinated sheep were found higher. The results for AV were in accordance with our other studies about water-oil marinating of horse meat evaluated by tested committee with lower scores due to negative rancid odor and taste [36].

3.2.2. Peroxide Value (POV). A similar tendency was found in primary products of lipid oxidation (Table 2). Compared to the control samples $\mathrm{C} 48$, the peroxide value in water-oil marinated sheep (WO48) increases by $9.7 \%$ and corresponds with the higher AV levels in the samples. The most significant increase by $20 \%(P \leq 0.05)$ in primary products of lipid oxidation was found after $48 \mathrm{~h}$ acid marination (AC48). In all other samples (AL48, BS48) the peroxide value was lower compared to control samples (C48). These results confirm the existence of induction period (Table 2) and formation and accumulation of lipid hydroperoxides which were converted into secondary products [37].

3.2.3. TBARS. The levels of TBARS of all studies samples vary in the range $0.22-0.65 \mathrm{mg}$ malondialdehyde $\cdot \mathrm{kg}^{-1}$ lipids, which is lower than the limit for fresh meat of $1.00 \mathrm{mg}$ malondialdehyde $\cdot \mathrm{kg}^{-1}$ lipids [37].

Acid marinating (AC24) increases by $44.44 \%(P \leq$ 0.05 ) the secondary products of lipid oxidation (Table 2).
In samples AL24, WO24, BS24, AL48, WO48, and BS48 the TBARS values were lower than those obtained for the control samples C24 and C48, respectively.

The results for alkaline marinated sheep confirmed many previous researches about antioxidant effect of phosphates $[13,32]$. Oppositely, the results obtained for lactate marinated meat (AC48) are difficult to explain. On the one hand many researches prove the antioxidant effect of sodium lactate $[9-11,36]$. On the other hand the data for POV and TBARS determination showed that lipid oxidation significantly increases after marinating with $2 \%$ sodium lactate. Our results confirm prooxidant action of the sodium lactate added as $2 \%$ marinating solution with $2 \%$ salt and are in accordance with previous studies about prooxidant action of the organic acids in beef loin steaks $[17,38]$.

Marinating with polyphosphates was the most effective method for inhibition of primary and secondary lipid oxidation products in sheep and confirms the previous researches for alkaline marinated beef [39].

3.2.4. Changes in Physicochemical Characteristics of Marinated Sheep. After $24 \mathrm{~h}$ treatment (Table 3), a $\mathrm{pH}$ in the alkaline marinated meat (AL24) increases by $6.5 \%(P \leq 0.05)$, followed by the meat soaked in a brine solution (BS24, 5.4\%, $P \leq 0.05)$ and water-oil marinated meat $(3.1 \%, P \leq 0.05)$.

After $24 \mathrm{~h}$ treatment, small but statistically significant $(P \leq 0.05)$ increase in $\mathrm{pH}$ was established in $2 \%$ acid marinated meat (AC24) (Table 3). Obviously, sodium lactate as salt of weak organic acid had a slight effect on meat $\mathrm{pH}$.

Oppositely after $48 \mathrm{~h}$ marinating the most significant increase in the meat $\mathrm{pH}$ was found in samples AL48 (with $8.77 \%$ ) and BS48 (with $7.69 \%, P \leq 0.05$, Table 3 ). The observed $\mathrm{pH}$ effect after alkaline marinating is expected and confirmed many other studies in poultry $[13,14]$ and beef [17].

After $24 \mathrm{~h}$ marinating the water holding capacity of samples AL24, AC24, and BS24 was not significantly different $(P>0.05$ (Table 3$)$ ). 

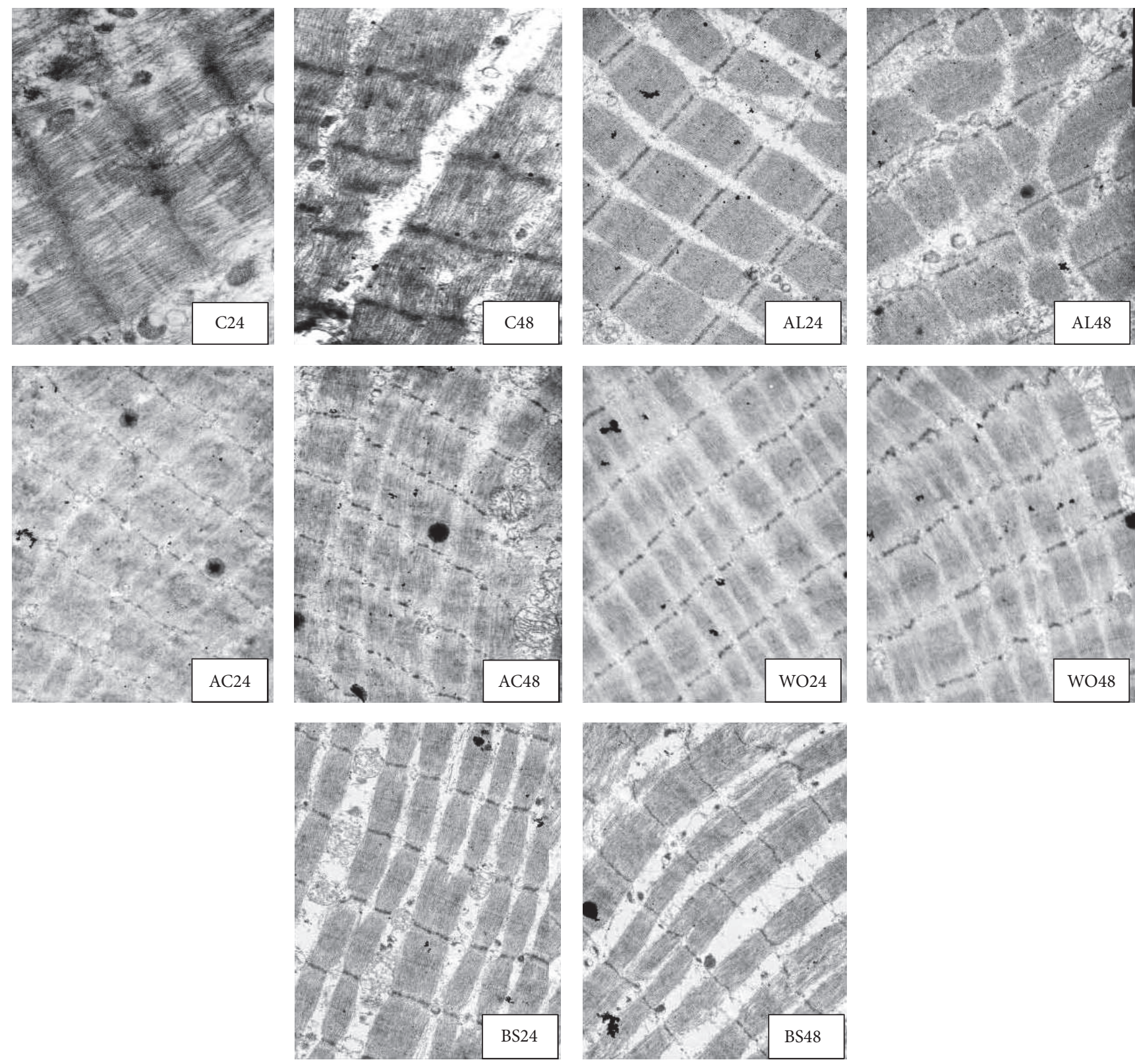

FIGURE 1: Electron micrographs of longitudinal section of marinated sheep (m. Longissimus dorsi), 12000x. C24: control sample stored at $0-4^{\circ} \mathrm{C}$ in air conditions for $24 \mathrm{~h}$; C48: control sample stored at $0-4^{\circ} \mathrm{C}$ for $48 \mathrm{~h}$; AL24: test sample after $24 \mathrm{~h}$ alkaline marinating; AL48: test sample after $48 \mathrm{~h}$ alkaline marinating; AC24: test sample after $24 \mathrm{~h}$ acid marinating; AC48: test sample after $48 \mathrm{~h}$ acid marinating; WO24: test sample after $24 \mathrm{~h}$ water-oil marinating; WO48: test sample after $48 \mathrm{~h}$ water-oil marinating; BS24: test sample after $24 \mathrm{~h}$ brine soaking; BS48: test sample after $48 \mathrm{~h}$ brine soaking.

It was surprising that after $48 \mathrm{~h}$ marinating the water holding capacity was highest in brine treated meat (BS48) followed by alkaline marinated meat (AL48) $(P>0.05)$ (Table 3).

It is known that the comparatively high $\mathrm{pH}$ during alkaline marinating increases water holding capacity [6]. The expected effect from phosphate marinating on WHC was not observed. One possible reason was that the high $\mathrm{pH}$ in meat for marinating (6.95) leads to strong effect after soaking in brine solution.
The least impact on meat water holding capacity (Table 3) and brine absorption (Table 3 ) was found after water-oil marinating (WO24, WO48). Probable reason for this finding was the high salt concentration in the aqueous phase of the wateroil marinade solution. The water-oil emulsion was prepared from water and plant oil (1:1). Therefore the salt concentration in the aqueous phase in water-oil emulsion reaches $4 \%$. As is known the brine absorption in meat during the soaking increases up to salt concentrations of $0.34 \mathrm{~mol} \cdot \mathrm{L}^{-1}$ (approximately $3 \% \mathrm{NaCl}$ in brine) and then decreased [40]. 


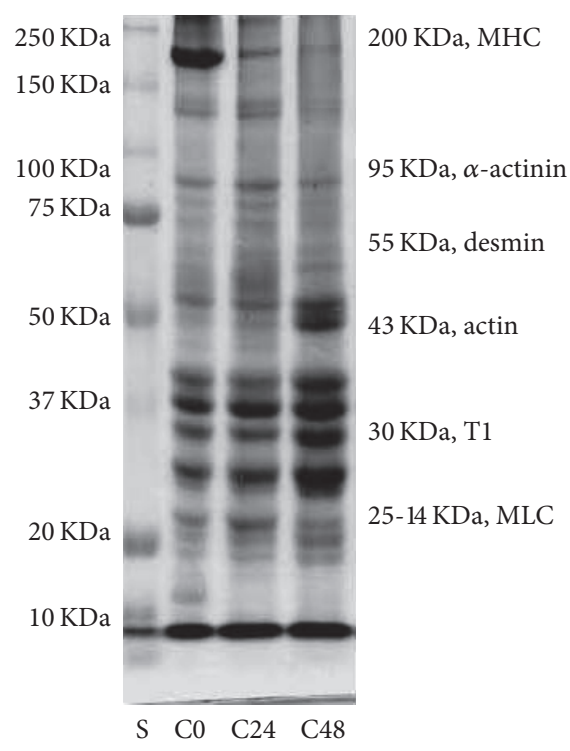

FIGURE 2: SDS-PAGE electrophoresis of control samples sheep ( $m$. Longissimus dorsi), stored in air conditions at $0-4^{\circ} \mathrm{C}$. S: standard; $\mathrm{C} 0$ : control samples at $4 \mathrm{~h}$ postmortem; C24: control samples stored in air conditions at $0-4^{\circ} \mathrm{C}$ for $24 \mathrm{~h}$; C48: control samples stored in air conditions at $0-4^{\circ} \mathrm{C}$ for $48 \mathrm{~h}$.

We can conclude that due to $4 \%$ salt concentration in aqueous phase the estimated lower WHC was normal.

The weight gain increased after alkaline (AL) and acid (AC) marinating, as well as brine soaking (BS) and were in accordance with the data for WHC and $\mathrm{pH}$.

It was interesting that the cooking loss was minimal after water-oil marinating (WO24, WO48). The lowest brine absorption in water-oil marinated sheep can explain this finding (Table 3).

The opposite trend was established in samples BS24 and BS48 where brine absorption was greatest, but in these samples the loss was biggest $(P \leq 0.05)$ after cooking. Despite higher WHC and brine absorption, only the use of $2 \%$ salt solution does not have effect on marinade retention after roasting (Table 3 ).

The alkaline marinating with $2 \%$ polyphosphates and acid marinating with $2 \%$ sodium lactate contribute to penetration and retention of marinade solutions in muscle tissue. The results confirm the triple action of phosphates on muscle tissue: increasing of $\mathrm{pH}$, effect on ionic strength, and myosin extraction from myofibrillar structures in meat [32].

The least impact on the technological properties was established after water-oil marinating (Table 3).

3.2.5. Microstructural Changes in Marinated Sheep. After $24 \mathrm{~h}$ alkaline marinating ( $m$. Longissimus dorsi) due to the penetration of the marinade solution the myofibrils had "garland" form (AL24, Figure 1). The native structure of myofibrils in sample was preserved. The myofibrils were similar to the control with clearly defined A- and I-bands, $\mathrm{H}$-zones, and $\mathrm{M}$ lines. Our results confirm Komoltri and Pakdeechanuan [41] hypothesis that the use of phosphates opened the protein grid and increased the amount of retained water in myofibrils. As a result the space between myofibrils was increasing.

Wavy myofibril with longitudinal cuts was observed after $48 \mathrm{~h}$ alkaline marinating (AL48, Figure 1). Z-disks fragmentation and large gaps formation were an indicator for deep destructive processes in the muscle fibers. This observation was confirmed by lower soluble proteins in AL48 than those in AL24 suggesting no more destructuration of myofibrils (Table 1). TEM observation was in accordance with higher WHC and brine absorption after alkaline marinating (Table 3).

After $24 \mathrm{~h}$ acid marinating (AC24, Figure 1) A-, I-, and Hzones and the M-lines were difficultly identifiable (AC48, Figure 1). Fragmentation in the sarcomeres and Z-lines destructions showed deeper destructive changes with the prolonging of acid marination to $48 \mathrm{~h}$. However, the microstructural changes after $48 \mathrm{~h}$ acid marination were slighter than changes observed in $48 \mathrm{~h}$ alkaline marinated sheep (AL48, Figure 1). This result confirmed SDS-PAGE electrophoresis of marinated (Figure 3) meat and the data established for protein solubility and FAN content (Table 1). But, opposite to phosphates, acid marinating solutions affect native structure of connective tissue due to proteases activation $[42,43]$.

Slight impact on myofibrillar structure was found after water-oil marinating. Individual sarcomeres were undamaged. A- and I-zones were clearly distinguished. Because of the slight penetration of marinate solution the impact on myofibrils was minimal (WO24, Figure 1).

Marinating in water-oil emulsions for $48 \mathrm{~h}$ had little impact on the muscle microstructure. Z-disks and A- and Izones were distinguished, and the native structure of myofibrils was preserved (WO48).

Significant increasing of space between myofibrils was observed after $24 \mathrm{~h}$ soaking in $2 \%$ sodium chloride (BS24). Z-lines are undamaged, and A-, I-, H-zones and M-lines are clearly visible.

Penetration of the brine (BS24) in myofibrillar spaces produces longitudinal fissures in the sarcomeres. H-zones were dispersed, but myofibrillar structure was undamaged. Identified microstructural changes of soaked sheep confirmed the data obtained for water absorption (Table 3).

Despite significant swelling and brine penetration after soaking, the reported cooking losses in these samples increased significantly (Table 3 ).

Our results confirm that soaking had the most significant impact on the solubility of the protein fraction (Table 1) and increased brine penetration and water holding capacity (Table 3) to the maximal extent but does not contribute to retention of the brine (Table 3 ) in marinated sheep.

\section{Conclusions}

We can conclude that the alkaline marinating with $2 \%$ polyphosphates and acid marination with $2 \%$ sodium lactate improve the water holding capacity, solubility of the protein fraction, and marinade uptake.

The brine solution greatly enhances the solubility of the protein fraction but does not contribute to the stable brine retention after heating. 


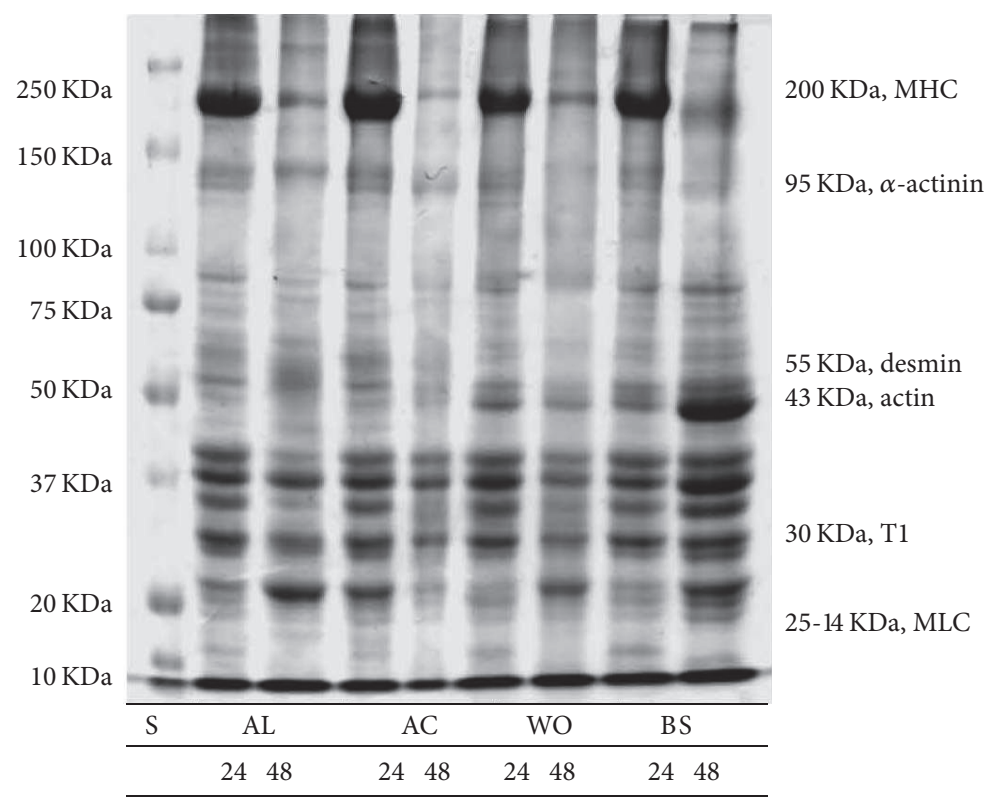

FIGURE 3: SDS-PAGE electrophoresis of marinated sheep. S: standard; AL24: test sample after $24 \mathrm{~h}$ alkaline marinating; AL48: test sample after $48 \mathrm{~h}$ alkaline marinating; AC24: test sample after $24 \mathrm{~h}$ acid marinating; AC48: test sample after $48 \mathrm{~h}$ acid marinating; WO24: test sample after $24 \mathrm{~h}$ water-oil marinating; WO48: test sample after $48 \mathrm{~h}$ water-oil marinating; BS24: test sample after $24 \mathrm{~h}$ brine soaking; BS48: test sample after $48 \mathrm{~h}$ brine soaking.

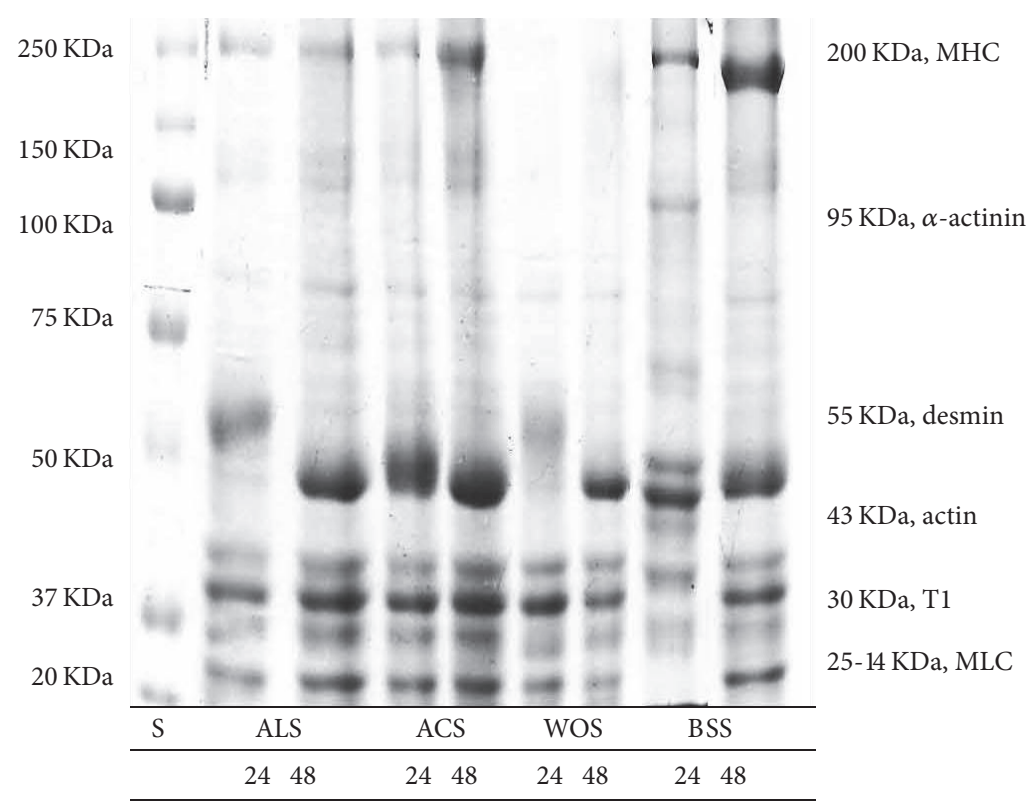

FIGURE 4: SDS-PAGE electrophoresis of marinating solutions. S: standard; ALS24: alkaline marinating solution after 24 h treatment; ALS48: alkaline marinating solution after $48 \mathrm{~h}$ treatment; ACS24: acid marinating solution after $24 \mathrm{~h}$ treatment; ACS48: acid marinating solution after $48 \mathrm{~h}$ treatment; WOS24: water-oil emulsion after $24 \mathrm{~h}$ treatment; WOS48: water-oil emulsion after $48 \mathrm{~h}$ treatment; BSS24: brine solution after $24 \mathrm{~h}$ treatment; BSS48: brine solution after $48 \mathrm{~h}$ treatment.

The water-oil marinating increases the hydrolysis processes in lipid fraction from sheep.

The alkaline marinating with $2 \%$ of sodium tripolyphosphate inhibits protein and lipid oxidation, while the acid marinating with $2 \%$ sodium lactate had the prooxidant effect and increased the protein and lipid oxidation in sheep.
The most significant destructive changes in the sheep muscle structure were established after $48 \mathrm{~h}$ marinating.

\section{Competing Interests}

The authors declare that they have no competing interests. 


\section{Acknowledgments}

This work was supported by the University of Food Technologies, Plovdiv, Bulgaria.

\section{References}

[1] S. Latif, "Effect of marination on the quality characteristics and microstructure of chicken breast meat cooked by different methods," Seria Zootehnie Lucrări Știintifice, vol. 54, pp. 314324, 2011.

[2] R. Narayan, S. K. Mendiratta, and B. G. Mane, "Effects of citric acid, cucumis powder and pressure cooking on quality attributes of goat meat curry," Journal of Food Science and Technology, vol. 52, no. 3, pp. 1772-1777, 2015.

[3] S. D. Shackelford, T. L. Wheeler, M. K. Meade, J. O. Reagan, B. L. Byrnes, and M. Koohmaraie, "Consumer impressions of tender select beef," Journal of Animal Science, vol. 79, no. 10, pp. 26052614, 2001.

[4] E. H. Lonergan, W. Zhang, and S. M. Lonergan, "Biochemistry of postmortem muscle-lessons on mechanisms of meat tenderization," Meat Science, vol. 86, no. 1, pp. 184-195, 2010.

[5] H. Ergezer and R. Gokce, "Comparison of marinating with two different types of marinade on some quality and sensory characteristics of Turkey breast meat," Journal of Animal and Veterinary Advances, vol. 10, no. 1, pp. 60-67, 2011.

[6] S. Barbut, "Poultry products-formulation and gelation," in Poultry Products Processing. An Industry Guide, S. Barbut, Ed., pp. 249-288, CRC Press, New York, NY, USA, 2002.

[7] H. C. Bertram, R. L. Meyer, Z. Wu, X. Zhou, and H. J. Andersen, "Water distribution and microstructure in enhanced pork," Journal of Agricultural and Food Chemistry, vol. 56, no. 16, pp. 7201-7207, 2008.

[8] M. Zheng, N. A. Detienne, B. W. Barnes, and L. Wicker, "Tenderness and yields of poultry breast are influenced by phosphate type and concentration of marinade," Journal of the Science of Food and Agriculture, vol. 81, no. 1, pp. 82-87, 2001.

[9] S. Ke, Effect of $p H$ and salts on tenderness and water-holding capacity of muscle foods [Ph.D. thesis], University of Massachusetts, Amherst, Mass, USA, 2006, http://scholarworks .umass.edu/dissertations/AAI3215890.

[10] J. B. Hinkle, Acid marination for tenderness enhancement of beef bottom round [thesis for the Degree of MSc in Animal Science], University of Nebraska, Lincoln, Neb, USA, 2010.

[11] P. Berge, P. Ertbjerg, L. M. Larsen, T. Astruc, X. Vignon, and A. J. Møller, "Tenderization of beef by lactic acid injected at different times post mortem," Meat Science, vol. 57, no. 4, pp. 347-357, 2001.

[12] J. Gutierrez, C. Barry-Ryan, and P. Bourke, "Antimicrobial activity of plant essential oils using food model media: efficacy, synergistic potential and interactions with food components," Food Microbiology, vol. 26, no. 2, pp. 142-150, 2009.

[13] C. Alvarado and S. McKee, "Marination to improve functional properties and safety of poultry meat," Journal of Applied Poultry Research, vol. 16, no. 1, pp. 113-120, 2007.

[14] M. Petracci, L. Laghi, P. Rocculi et al., "The use of sodium bicarbonate for marination of broiler breast meat," Poultry Science, vol. 91, no. 2, pp. 526-534, 2012.

[15] C. D. Carroll, C. Z. Alvarado, M. M. Brashears, L. D. Thompson, and J. Boyce, "Marination of turkey breast fillets to control the growth of Listeria monocytogenes and improve meat quality in deli loaves," Poultry Science, vol. 86, no. 1, pp. 150-155, 2007.
[16] Y. J. Kim, S. K. Jin, W. Y. Park, B. W. Kim, S. T. Joo, and H. S. Yang, "The effect of garlic or onion marinade on the lipid oxidation and meat quality of pork during cold storage," Journal of Food Quality, vol. 33, no. 1, pp. 171-185, 2010.

[17] T. E. Lawrence, M. E. Dikeman, M. C. Hunt, and C. L. Kastner, "Effects of injection marination with various calcium sources and molar concentrations on display colour life, tenderness, and microbial inhibition of beef loin steaks," in Proceedings of the Conference: Cattlemen's Day, March 1, 2002, M. C. Hunt, Ed., pp. 102-105, Kansas State University, Agricultural Experiment Station and Cooperative Extension Service, Manhattan, NY, USA, 2002.

[18] N. Aktaş, M. I. Aksu, and M. Kaya, "The effect of organic acid marination on tenderness, cooking loss and bound water content of beef," Journal of Muscle Foods, vol. 14, no. 3, pp. 181194, 2003.

[19] S. Q. Xu, G. H. Zhou, Z. Q. Peng, L. Y. Zhao, and R. Yao, “The influence of polyphosphate marination on simmental beef shear value and ultrastructure," Journal of Muscle Foods, vol. 20, no. 1, pp. 101-116, 2009.

[20] A. Önenç, M. Serdaroğlu, and K. Abdraimov, "Effect of various additives to marinating baths on some properties of cattle meat," European Food Research and Technology, vol. 218, no. 2, pp. 114117, 2004.

[21] T. E. Lawrence, A. T. Waylan, and C. L. Kastner, "Myofibrillar structural changes caused by marination with calcium phosphate or calcium chloride and sodium pyrophosphate," in Proceedings of the Conference of Cattlemen's Day, M. C. Hunt, Ed., pp. 102-105, Kansas State University. Agricultural Experiment Station and Cooperative Extension Service, Manhattan, Kan, USA, March 2002.

[22] A. W. Khan, "Extraction and fractionation of proteins in fresh chicken muscle," Journal of Food Science, vol. 27, no. 5, pp. 430434, 1962.

[23] O. H. Lowry, N. J. Rosebrough, A. L. Farr, and R. J. Randall, "Protein measurement with the Folin phenol reagent," The Journal of Biological Chemistry, vol. 193, no. 1, pp. 265-275, 1951.

[24] J. M. Lorenzo, M. C. García Fontán, I. Franco, and J. Carballo, "Proteolytic and lipolytic modifications during the manufacture of dry-cured lacón, a Spanish traditional meat product: effect of some additives," Food Chemistry, vol. 110, no. 1, pp. 137-149, 2008.

[25] M. S. Serikkaisai, D. B. Vlahova-Vangelova, S. G. Dragoev, Y. M. Uzakov, and D. K. Balev, "Effect of dry goji berry and pumpkin powder on quality of cooked and smoked beef with reduced nitrite content," Advance Journal of Food Science and Technology, vol. 6, no. 7, pp. 877-883, 2014.

[26] K. J. Frost, L. F. Lowry, J. M. Ver Hoef, S. J. Iverson, and M. A. Simpkins, Monitoring, Habitat Use, and Trophic Interactions of Harbor Seals in Prince William Sound, Alaska. Exxon Valdez, 1997.

[27] E. Kardash and Y. I. Tur'yan, "Acid value determination in vegetable oils by indirect titration in aqueous-alcohol media," Croatica Chemica Acta, vol. 78, no. 1, pp. 99-103, 2005.

[28] A. Schmedes and G. Hølmer, "A new thiobarbituric acid (TBA) method for determining free malondialdehyde (MDA) and hydroperoxides selectively as a measure of lipid peroxidation," Journal of the American Oil Chemists Society, vol. 66, no. 6, pp. 813-817, 1989.

[29] N. A. Botsoglou, D. J. Fletouris, G. E. Papageorgiou, V. N. Vassilopoulos, A. J. Mantis, and A. G. Trakatellis, "Rapid, sensitive, and specific thiobarbituric acid method for measuring lipid 
peroxidation in animal tissue, food, and feedstuff samples," Journal of Agricultural and Food Chemistry, vol. 42, no. 9, pp. 1931-1937, 1994.

[30] O. A. Young, J. West, A. L. Hart, and F. F. H. van Otterdijk, "A method for early determination of meat ultimate $\mathrm{pH}$," Meat Science, vol. 66, no. 2, pp. 493-498, 2004.

[31] M. Modzelewska-Kapitula and M. Cierach, "Effect of pressure and sample weight on free water content in beef estimated according to Grau-Hamm method using computer image analysis," Nauka PrzyrodaTechnologie, vol. 3, pp. 1-6, 2009.

[32] N. H. Bach Son Long, R. Gál, and F. Buňka, "Use of phosphates in meat products," African Journal of Biotechnology, vol. 10, no. 86, pp. 19874-19882, 2011.

[33] S. Ketnawa and S. Rawdkuen, "Application of bromelain extract for muscle foods tenderization," Food and Nutrition Sciences, vol. 2, no. 5, pp. 393-401, 2011.

[34] S. E. Harris, E. Huff-Lonergan, S. M. Lonergan, W. R. Jones, and D. Rankins, "Antioxidant status affects color stability and tenderness of calcium chloride-injected beef," Journal of Animal Science, vol. 79, no. 3, pp. 666-677, 2001.

[35] D. Sharedeh, P. Gatellier, T. Astruc, and J.-D. Daudin, "Effects of $\mathrm{pH}$ and $\mathrm{NaCl}$ levels in a beef marinade on physicochemical states of lipids and proteins and on tissue microstructure," Meat Science, vol. 110, pp. 24-31, 2015.

[36] D. B. Vlahova-Vangelova, S. Abjanova, and S. G. Dragoev, "Influence of the marinating type on the morphological and sensory properties of horse meat," Acta Scientiarum Polonorum, Technologia Alimentaria, vol. 13, no. 4, pp. 403-411, 2014.

[37] S. Dragoev, "Control of lipid peroxidation in meat and meat products. A review," Meat and Meat Products, vol. 21, pp. 31-34, 2011 (Bulgarian).

[38] S. Ke, Y. Huang, E. A. Decker, and H. O. Hultin, "Impact of citric acid on the tenderness, microstructure and oxidative stability of beef muscle," Meat Science, vol. 82, no. 1, pp. 113-118, 2009.

[39] M. L. Sickler, Inhibition of lipid oxidation with phosphates in muscle foods [Thesis for the Degree of MSc in Food Science and Technology], Virginia Polytechnic Institute and State University, Blacksburg, Va, USA, 2000, https://vtechworks.lib.vt.edu/bitstream/handle/10919/31029/marsha.pdf?sequence=landisAllowed $=\mathrm{y}$.

[40] N. Aktaş, M. I. Aksu, and M. Kaya, "The influence of marination with different salt concentrations on the tenderness, water holding capacity and bound water content of beef," Turkish Journal of Veterinary and Animal Sciences, vol. 27, no. 5, pp. 1207-1211, 2003.

[41] P. Komoltri and P. Pakdeechanuan, "Effects of marinating ingredients on physicochemical, microstructural and sensory properties of golek chicken," International Food Research Journal, vol. 19, no. 4, pp. 1449-1455, 2012.

[42] S. Smaoui, H. B. Hlima, R. B. Salah, and R. Ghorbel, "Effects of sodium lactate and lactic acid on chemical, microbiological and sensory characteristics of marinated chicken," African Journal of Biotechnology, vol. 10, no. 54, pp. 11317-11326, 2011.

[43] D. Balcerzak, L. Querengesser, W. T. Dixon, and V. E. Baracos, "Coordinate expression of matrix-degrading proteinases and their activators and inhibitors in bovine skeletal muscle," Journal of Animal Science, vol. 79, no. 1, pp. 94-107, 2001. 

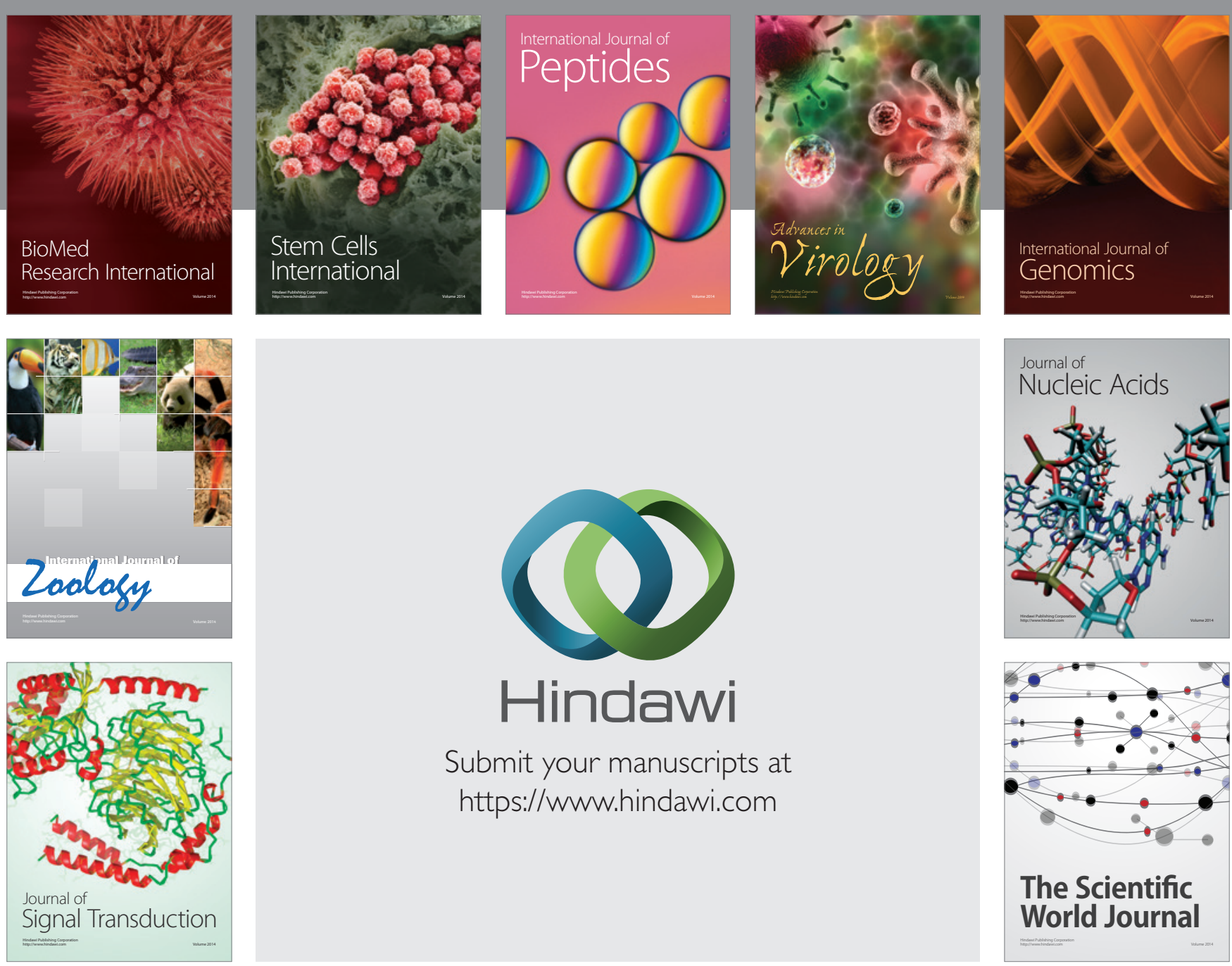

Submit your manuscripts at

https://www.hindawi.com
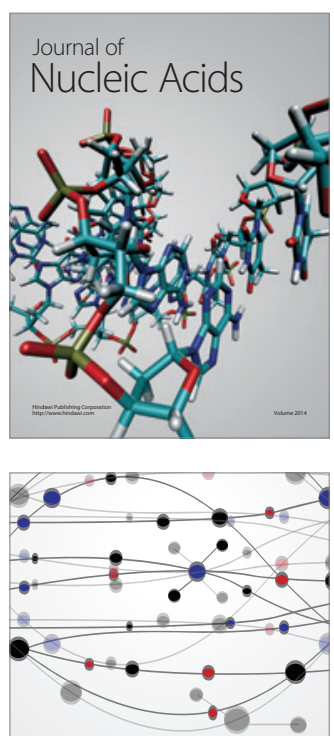

The Scientific World Journal
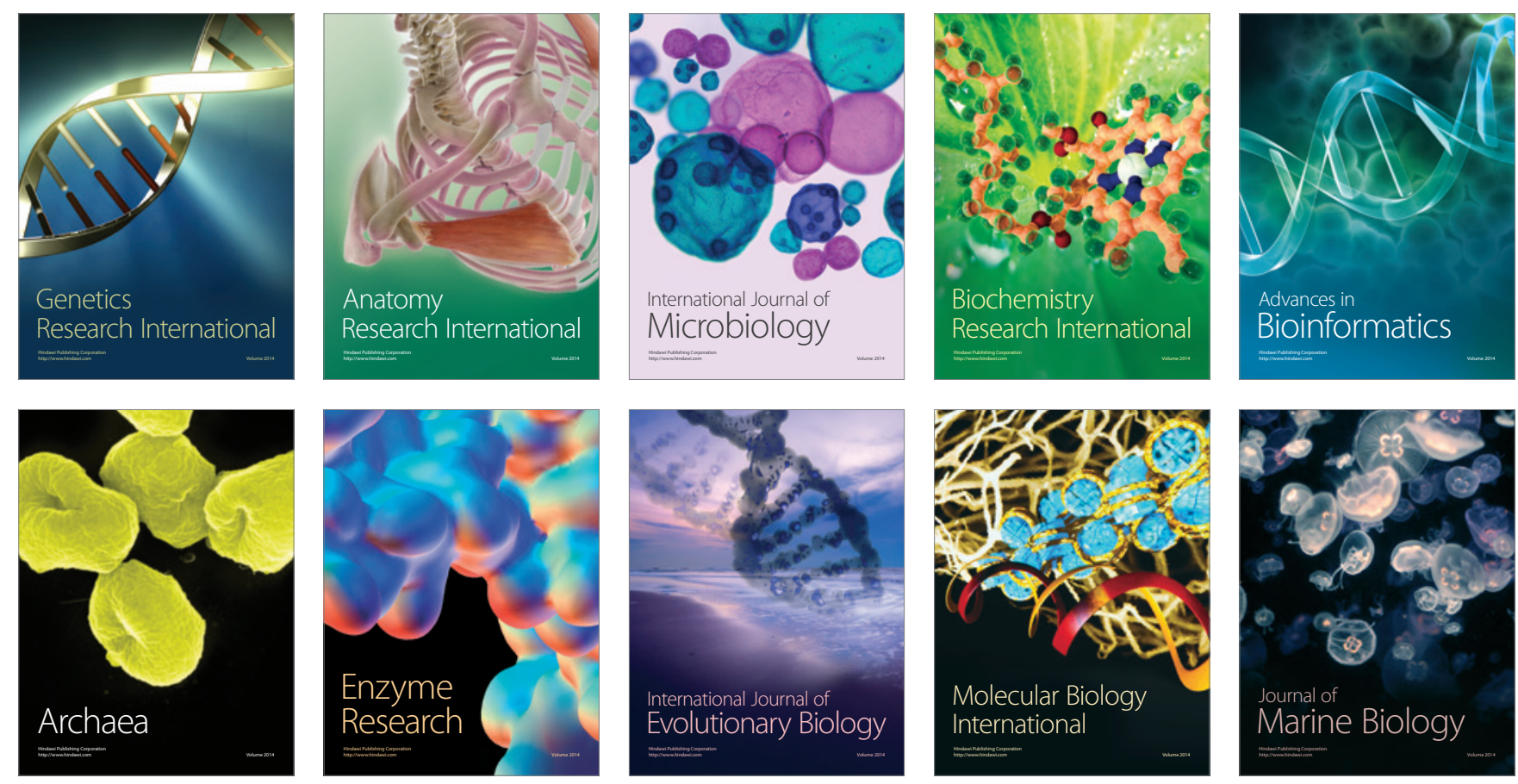